\title{
IDENTIFICAÇÃO MORFOLÓGICA E MOLECULAR DE Curvularia sp. AGENTE CAUSAL DA MANCHA FOLIAR DO MILHO
}

\author{
DALMARCIA DE SOUZA CARLOS MOURÃO ${ }^{1}$, SOLANGE APARECIDA SÁGIO ${ }^{1}$, \\ MICAELE RODRIGUES DE SOUZA ${ }^{1}$ e GIL RODRIGUES DOS SANTOS ${ }^{1}$
}

${ }^{1}$ Universidade Federaldo Tocantins,dalmarciaadm@uft.edu.br; micaele.sp@live.com; gilrsan@uft.edu.br, solsagio@gmail.com

Revista Brasileira de Milho e Sorgo, v.16, n.1, p. 1-12, 2017

\begin{abstract}
RESUMO - Fungos do gênero Curvularia são amplamente distribuídos ao redor do mundo, podendo estar associados a espécies vegetais, na forma saprofítica, endofítica ou como parasita. Espécies do referido gênero são responsáveis por diversas doenças em plantas cultivadas, causando principalmente manchas foliares. A correta identificação das espécies é importante para o conhecimento e manejo das doenças, sendo essas identificações baseadas principalmente em características morfológicas, como aspectos dos micélios, morfologia das hifas, formas e tamanho dos conídios. Entretanto, técnicas moleculares como a amplificação de genes específicos, além de análises do padrão de digestão de regiões ITS através de enzimas de restrição, têm contribuído para a identificação e diferenciação genética entre espécies. No presente trabalho foi realizada a caracterização morfológica e molecular de isolados de Curvularia oriundos de plantas de milho infectadas. Os isolados foram agrupados de acordo com a identificação morfológica e molecular, sendo que todos apresentaram o mesmo perfil de amplificação do DNA. As técnicas morfológicas e moleculares possibilitaram a caracterização de uma única espécie, Curvularia lunata.
\end{abstract}

Palavras-chave: Zea mays L., Curvularia lunata, morfologia, DNA, perfil de restrição.

\section{MORPHOLOGICAL AND MOLECULAR IDENTIFICATION OF Curvularia sp. CAUSAL AGENT OF CORN LEAF STAIN}

\begin{abstract}
Fungi of the genus Curvularia are widely distributed around the world and may be associated with plant species, in the saprophytic, endophytic or parasitic form. Species of this genus are responsible for several diseases in cultivated plants, causing mainly foliar stains. The correct identification of the species is important for the diseases knowledge and management, being these identifications based mainly on morphological characteristics as aspects of the mycelia, conidia forms and size, hyphae morphology. However, molecular techniques such as the amplification of specific genes, as well as digestion pattern analyzes of ITS regions through restriction enzymes, have contributed to the identification and genetic differentiation between species. In the present study, the morphological and molecular characterizations of Curvularia isolates from infected corn plants were realized. The isolates were grouped according to the morphological and molecular identification, all of which presented the same DNA amplification profile. Morphological and molecular techniques allowed the characterization of a single species, Curvularia lunata.
\end{abstract}

Keywords: Zea mays L. Curvularia lunata, morphology, DNA, restriction profile. 
O milho (Zea mays L.) é uma gramínea pertencente à família Poaceae e por causa da sua grande capacidade de acumulação de fotoassimilados é considerada uma das espécies mais eficientes em armazenamento de energia (Cruz et al., 2011).

É tratado como insumo para produção de centenas de produtos como, por exemplo, ração animal. $\mathrm{Na}$ cadeia produtiva de suínos e aves são consumidos aproximadamente $70 \%$ do milho produzido no mundo e entre 70 e $80 \%$ do milho produzido no Brasil (Duarte et al., 2012). A grande variedade de setores que utilizam o milho como matéria-prima coloca a cultura como um dos cereais mais produzidos, consumidos e também pesquisados (Afférri et al., 2008).

As tecnologias em melhoramento e controle de pragas e doenças, hoje disponíveis para o cultivo de milho, permitiram um avanço na área da produtividade. A diversidade de problemas que causam prejuízos à cultura do milho é muito grande, abrangendo diversas espécies, diferentes formas de controle, intensidade e dano econômico, segundo Galvão et al. (2014).

As doenças, principalmente aquelas causadas por fungos, podem comprometer o potencial de rendimento da cultura do milho (White, 1999), bem como das demais culturas de interesse econômico. Com a expansão da área cultivada de milho em plantio direto houve uma alteração no microclima e na biologia do agrossistema, com reflexos nas populações dos agentes causais das doenças (Reis et al., 2004). A presença dos restos culturais sobre a superfície do solo beneficia a sobrevivência de muitos fitopatógenos (Casa et al., 2006).

Dentre as doenças fúngicas foliares de grande distribuição no Brasil, a mancha-de-curvularia possui baixa frequência de relatos no meio científico (Cruz et al., 2000). Vaz-de-Melo et al. (2010) relataram o aumento da ocorrência da mancha-de-curvularia na região sul do Estado Tocantins nos últimos anos, encontrando efeito negativo na produtividade.

O reconhecimento das principais características morfológicas do gênero Curvularia é considerado fácil, o que possibilita a identificação dele (Lima \& Furtado, 2007). Entretanto, a confirmação de espécie deve ser feita com base não somente em características morfológicas, mas também com o auxílio de análises moleculares (Ferreira, 2010).

As técnicas moleculares têm auxiliado significativamente na identificação de espécies de fungos, bem como em estudos filogenéticos e taxonômicos, incluindo a diferenciação de agrupamentos intraespécies. Nos eucariontes, os genes que codificam o RNA ribossômico estão organizados em unidades repetidas em série agrupadas em uma ou mais regiões cromossômicas. Cada unidade possui sequências codificadoras altamente conservadas e sequências intercalares que, em geral, variam dentro e entre populações. (Long \& Dawid, 1980; Elder \& Turner, 1995). As regiões ITS (Internal Transcribed Spacer) que separam as unidades $18 \mathrm{~S}$ e $28 \mathrm{~S}$ dos genes ribossomais de eucariotos evoluem rapidamente, o que as tornam apropriadas para identificação de espécies relacionadas ou até mesmo variedades de uma mesma espécie.

As regiões ITS dispõem de características interessantes para a identificação dos fungos em nível molecular. Uma delas é que, nos fungos, esta região é amplificada, utilizando-se primers universais, os quais são complementares às sequências altamente conservadas que codificam os genes $18 \mathrm{~S}$ e $28 \mathrm{~S}$ de rRNA, sendo os primers ITS1 e ITS4 os mais comumente utilizados na amplificação por PCR e estudos de identificação de isolados e espécies (White et al., 1990).

Em razão dos poucos estudos desenvolvidos sobre a mancha-de-curvularia na cultura do milho no Estado do Tocantins, o presente estudo teve por 
objetivo a caracterização morfológica por meio de estudos macroscópicos e microscópicos do fitopatógeno Curvularia sp., e a caracterização molecular do patógeno por meio da amplificação do gene $C \lg 2 p$ espécie-específico para Curvularia lunata e análise do padrão de restrição do fragmento de DNA amplificado para a região ITS.

\section{Material e Métodos}

O experimento foi desenvolvido no ano de 2014 no Campo Experimental e no Laboratório de Fitopatologia do Campus de Gurupi da Universidade Federal do Tocantins (UFT). Folhas de plantas das cultivares BRS 1040, BM2202, Traktor, Attack e milho crioulo apresentando sintomas de mancha-decurvularia foram coletadas aleatoriamente para isolamento do patógeno.

Inicialmente as lesões presentes nas folhas foram cortadas em pequenos fragmentos com dimensões aproximadamente de $0,25 \mathrm{~cm}^{2}$ e em seguida passaram por um processo de desinfestação, em que as amostras foram mergulhadas em solução de álcool etílico a $70 \%$ por 30 segundos. Em seguida, as amostras foram transferidas para solução de hipoclorito de sódio a $1 \%$ por 40 segundos, e por último, lavadas três vezes em água destilada esterilizada e transferidas para meio de cultura BDA (Pimentel et al., 2006). As placas ficaram incubadas por sete dias em sala de incubação com fotoperíodo de $12 \mathrm{~h}$ de luz e temperatura de $25^{\circ} \mathrm{C} \pm 1{ }^{\circ} \mathrm{C}$.

Para a caracterização morfológica e microscópica, quinze isolados fúngicos foram cultivados por sete dias em meio BDA. Os isolados foram analisados por meio de microscópio óptico para identificação preliminar do fitopatógeno, o qual foi selecionado para obtenção de cultura monospórica e posterior confirmação de patogenicidade por meio dos Postulados de Koch.
A morfologia do patógeno da mancha-de-curvularia foi realizada por observações macroscópicas e microscópicas. As observações macroscópicas foram feitas em culturas incubadas a $25^{\circ} \mathrm{C} \pm 1{ }^{\circ} \mathrm{C}$ em meio BDA, em placas de Petri por sete dias. Após o crescimento micelial, as placas foram fotografadas.

Para caracterização morfológica, foi elaborada uma tabela na qual foram registrados: aspecto do micélio (cotonoso ou ralo), forma dos bordos (regulares ou não), coloração da colônia (preto, verde musgo ou cinza), reverso da colônia (com ou sem pigmentação escura), presença ou ausência de micélio sob o meio de cultura e também presença ou ausência de conídios em BDA, após sete dias de cultura (Ferreira, 2010).

A caracterização microscópica foi feita pela observação dos conídios (Ferreira, 2010). A obtenção dos conídios foi realizada pela técnica de microcultivo adaptada de Kern e Blevins (1999), em que foram utilizadas placas de Petri esterilizadas, contendo em seu interior uma lâmina, com um disco de aproximadamente $5 \mathrm{~cm}$ de diâmetro de meio de cultura BDA e sobre ela foi colocado o micélio do isolado, o qual foi posteriormente coberto por uma lamínula esterilizada. As placas foram incubadas por sete dias, a aproximadamente $25^{\circ} \mathrm{C} \pm 1{ }^{\circ} \mathrm{C}$.

Para esta análise utilizaram-se três conídios de cada isolado. As visualizações das estruturas de reprodução foram feitas em microscópio óptico e as imagens, captadas com o auxílio do software TSView7, em que foram analisadas e mensuradas.

As análises moleculares foram realizadas no Laboratório de Manejo Integrado de Plantas na Universidade Federal do Tocantins. Para a identificação molecular, foram utilizados isolados de cinco cultivares (BRS 1040, BM2202, Traktor, Attack e milho crioulo). Para a extração de DNA, primeiramente os isolados foram cultivados em meio de cultura BDA e incubados por sete dias a $25{ }^{\circ} \mathrm{C} \pm 1{ }^{\circ} \mathrm{C}$. Discos de 
BDA contendo o micélio do fungo foram excisados e inoculados em $60 \mathrm{ml}$ de meio líquido contendo $10 \mathrm{~g}$ de extrato de levedura, $10 \mathrm{~g}$ de dextrose, $1 \mathrm{~L}$ de água destilada e antibiótico (Cloranfenicol) na concentração de $200 \mathrm{mg} / \mathrm{L}$. Posteriormente, as culturas foram mantidas em agitação (120 rpm) durante sete dias a 25 ${ }^{\circ} \mathrm{C}$, para o crescimento do micélio. Após este período, o micélio foi separado do meio líquido por filtração a vácuo, lavado com água destilada estéril, coletado e imediatamente colocado em nitrogênio líquido para maceração com o auxílio de graal e pistilo. A extração do DNA foi efetuada pelo método CTAB descrito por Zolan e Pukilla (1986), com algumas modificações conforme segue. Cerca de $0,5 \mathrm{~g}$ do micélio foi suspenso em $1 \mathrm{ml}$ de tampão de extração CTAB pré-aquecido a $65{ }^{\circ} \mathrm{C}[2 \% \mathrm{p} / \mathrm{v}$ de $\mathrm{CTAB} ; 2,5 \% \mathrm{p} / \mathrm{v}$ de PVP; $2 \mathrm{M}$ de $\mathrm{NaCl} ; 100$ mM Tris-HCl (pH 8,0), 25 mM EDTA $\mathrm{pH} 8,0]$, adicionado de beta-mercaptoetanol 2\% (v/v). Após homogeneização da mistura, as amostras foram incubadas por 40 minutos a $65^{\circ} \mathrm{C}$. Em seguida, procedeu-se a centrifugação por 10 minutos a $11.000 \mathrm{rpm}$ e a fase aquosa foi recolhida para extração com clorofórmio/álcool isoamílico (24:1). O RNA presente nas amostras foi degradado por tratamento com RNase A $(50 \mathrm{mg} / \mathrm{ml})$ durante $30 \mathrm{~min}$ a $37^{\circ} \mathrm{C}$. Em seguida, o DNA foi precipitado pela adição de 2,5 volumes de etanol absoluto e sedimentado por centrifugação durante $15 \mathrm{~min}$ a $12.000 \mathrm{rpm}$. O pellet foi lavado com etanol a 70\%, e suspenso em água ultrapura. A concentração de DNA das amostras foi determinada por leitura em espectrofotômetro (Biowave DNA) a 260 $\mathrm{nm}$, e a pureza foi verificada pela relação $A_{260 / 280 \mathrm{~nm}}$.

Para a caracterização molecular dos isolados, foram utilizados os primers P1: (5' ATGGACGAGAACAACAGGATAACGA- 3') e P2: (5'-CTA CCAGCATTTAAGTTTACTCCAG-3') (Hou et al., 2013) baseados na sequência nucleotídica do gene
Clg2p (Cochliobolus lunatus). Cada reação de amplificação foi realizada em um volume final de $25 \mu \mathrm{L}$, composto por 2,5 ng de DNA genômico; $13 \mu \mathrm{L}$ de água estéril; $10 \mathrm{mM}$ de Tris- $\mathrm{HCl} ; 2 \mathrm{mM}$ de $\mathrm{MgCl}$; $0,1 \mathrm{mM}$ de dNTPs; $1.25 \mathrm{U}$ de Taq DNA polimerase (Ludwing); 0,4 $\mu \mathrm{M}$ de cada primer. As reações de amplificação foram incubadas em termociclador (Techne TC-500), com os seguintes ciclos: etapa de desnaturação a $95{ }^{\circ} \mathrm{C}$ por $4 \mathrm{~min}$, etapa de anelamento a 55 ${ }^{\circ} \mathrm{C}$ por $1 \mathrm{~min}$, e etapa de extensão a $72{ }^{\circ} \mathrm{C}$ por $2 \mathrm{~min}$. Após 40 ciclos, as reações foram finalizadas com um ciclo adicional de extensão a $72{ }^{\circ} \mathrm{C}$ por 5 min.

A amplificação da região ITS dos isolados foi feita com os primers universais ITS1 (5' -TCCGTTGGTGAACCAGCG G-3') e ITS4 (5'- TCCTCCGCTTATTGATATGC-3') (White et al., 1990). A reação de amplificação foi realizada em volume final de $20 \mathrm{uL}$, utilizando o kit GoTaq ${ }^{\circledR}$ DNA Polymerase, sendo $4 \mathrm{uL}$ do tampão de reação, $2 \mathrm{uL}$ de Cloreto de Magnésio, 1uL de dNTP (100 mM), 1 $\mathrm{uL}$ de cada primer $(\mathrm{F} / \mathrm{R}), 0,3 \mathrm{uL}$ da enzima Gotaq (Promega) e 1 uL de DNA molde (50ng) e 9,7 uL de água deionizada estéril. As reações de amplificação foram submetidas ao termociclador (Techne TC500), com os seguintes ciclos: desnaturação inicial por 2 minutos a $95{ }^{\circ} \mathrm{C}$, seguido de 38 ciclos sendo desnaturação a $95^{\circ} \mathrm{C}$ por 30 segundos, anelamento por 1 minuto a $51{ }^{\circ} \mathrm{C}$, extensão por 1 minuto a 72 ${ }^{\circ} \mathrm{C}$, antes da extensão final de 5 minutos a $72{ }^{\circ} \mathrm{C}$. Todos os produtos das reações foram visualizados em gel de agarose a 1,4\% corado com Blue Green (LGC Biotecnologia), as imagens foram recolhidas por meio de um fotodocumentador (Gel Logic 112).

Os produtos da amplificação da região ITS dos genes ribossomais foram empregados nas análises do perfil de restrição enzimática. Alíquota de 10 $\mathrm{uL}$ de cada produto foi misturada com 10 unidades 
de enzimas de restrição HaeIII, de acordo com as instruções do fabricante (Jena Bioscience) e incubadas por 15 minutos em temperatura de $37^{\circ} \mathrm{C}$. Os fragmentos de restrição, foram separados em gel de agarose a 2,5\%, por 45 minutos a $110 \mathrm{~V}$ e $400 \mathrm{~mA}$. As amostras foram coradas com Blue Green (LGC Biotecnologia) e o perfil de restrição foi visualizado em fotodocumentador.

\section{Resultados e Discussão}

No presente estudo, todos os isolados de Curvularia sp. foram reisolados de plantas inoculadas, e a patogenicidade deles pelo postulado de Koch.
Com base na caracterização morfológica, os isolados de Curvularia sp. apresentaram micélio ralo $(66,67 \%)$ e cotonoso $(33,33 \%)$, em meio de cultivo BDA. Quanto às formas do bordo, todos os isolados foram regulares. Em relação à pigmentação da cor da colônia, o padrão variou entre cinza e branco, prevalecendo a cor cinza em $86,66 \%$ dos isolados. O reverso das colônias sempre apresentou coloração escura. A presença de conídios foi observada em todos os isolados após os sete dias de incubação a $25^{\circ} \mathrm{C}$. Quanto ao crescimento das colônias, variou entre 68,35 e 90 cm de diâmetro (Tabela 1).

Segundo Lima e Furtado (2007), o reconhecimento das principais características morfológicas do

Tabela 1. Características morfológicas de isolados de Curvularia sp. obtidos de lesões foliares de cultivares de milho na localidade de Gurupi-Tocantins.

\begin{tabular}{|c|c|c|c|c|c|c|c|}
\hline \multicolumn{8}{|c|}{$\begin{array}{c}\text { Características morfológicas } \\
\text { (Colônia) }\end{array}$} \\
\hline Cultivar & Isolado & $\begin{array}{l}\text { Aspecto } \\
\text { do micélio }\end{array}$ & $\begin{array}{l}\text { Forma do } \\
\text { bordo }\end{array}$ & $\begin{array}{l}\text { Cor da } \\
\text { colônia }\end{array}$ & $\begin{array}{l}\text { Reverso da } \\
\text { colônia }\end{array}$ & $\begin{array}{l}\text { Presença ou ausência de } \\
\text { conídio }\end{array}$ & $\begin{array}{l}\text { Crescimento } \\
\text { micelial* }\end{array}$ \\
\hline \multirow[t]{3}{*}{ BRS 1040} & I1 1 & Ralo & Regular & Cinza & Escura & Presente & 73,81 \\
\hline & I1 2 & Ralo & Regular & Cinza & Escura & Presente & 75,21 \\
\hline & I1 3 & Ralo & Regular & Cinza & Escura & Presente & 82,2 \\
\hline \multirow[t]{3}{*}{ BM2202 } & I2 4 & Ralo & Regular & Cinza & Escura & Presente & 72,39 \\
\hline & I2 5 & Ralo & Regular & Cinza & Escura & Presente & 71,28 \\
\hline & I2 6 & Ralo & Regular & Cinza & Escura & Presente & 74,54 \\
\hline \multirow[t]{3}{*}{ Traktor } & I3 7 & Ralo & Regular & Cinza & Escura & Presente & 68,35 \\
\hline & I3 8 & Ralo & Regular & Cinza & Escura & Presente & 72,38 \\
\hline & I3 9 & Ralo & Regular & Cinza & Escura & Presente & 66,72 \\
\hline \multirow[t]{3}{*}{ Attack } & I4 10 & Cotonoso & Regular & Branca & Escura & Presente & 68,47 \\
\hline & I4 11 & Cotonoso & Regular & Cinza & Escura & Presente & 77,62 \\
\hline & I4 12 & Cotonoso & Regular & Cinza & Escura & Presente & 82,47 \\
\hline \multirow{3}{*}{$\begin{array}{l}\text { Milho } \\
\text { crioulo }\end{array}$} & I5 13 & Ralo & Regular & Branca & Escura & Presente & 71,55 \\
\hline & I5 14 & Cotonoso & Regular & Cinza & Escura & Presente & 81,13 \\
\hline & I5 15 & Cotonoso & Regular & Cinza & Escura & Presente & 90 \\
\hline
\end{tabular}

*Diâmetro médio da colônia (C e L, sendo C: Comprimento e L: Largura). 


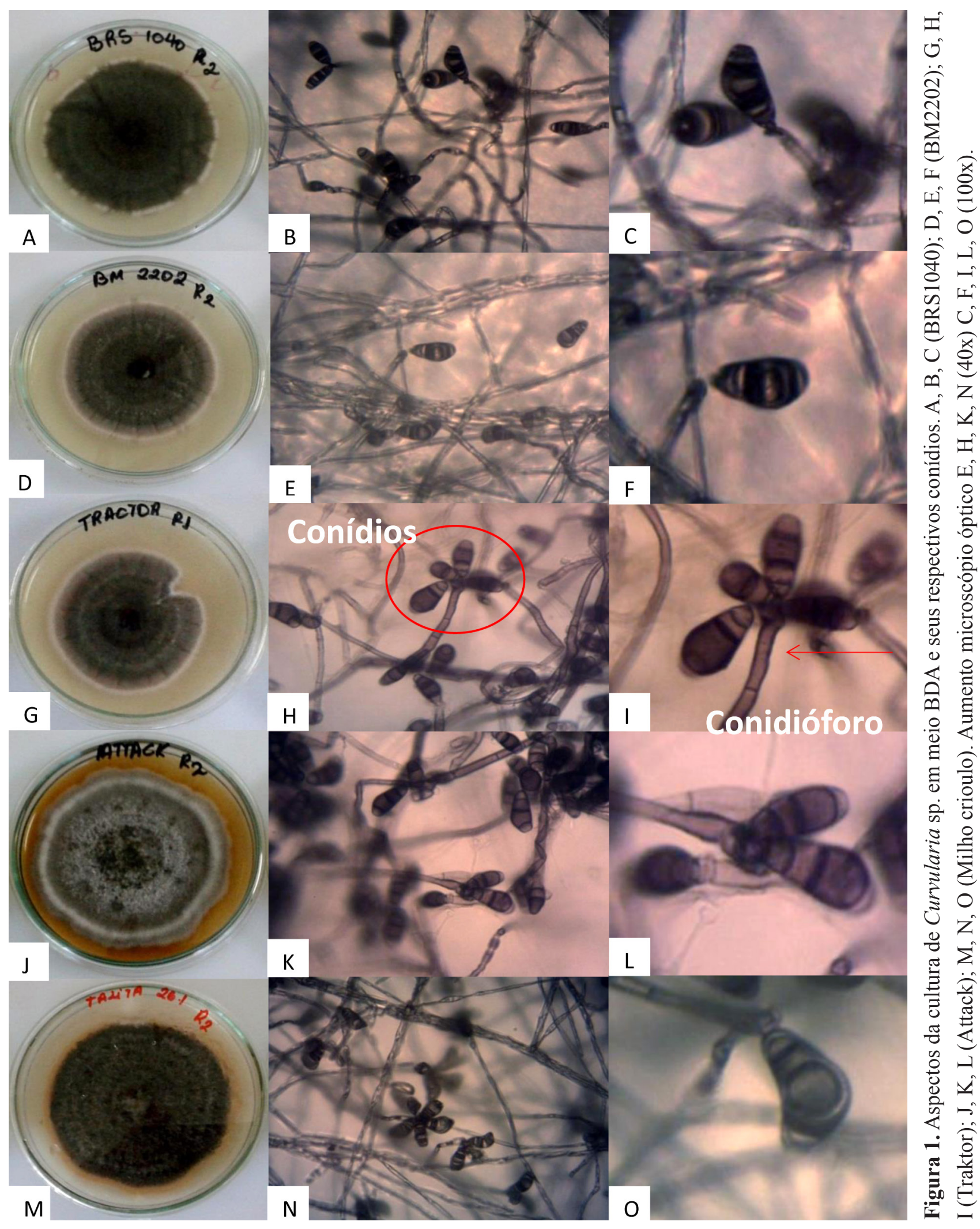

Revista Brasileira de Milho e Sorgo, v.16, n.1, p. 1-12, 2017

Versão impressa ISSN 1676-689X / Versão on line ISSN 1980-6477 - http://www.abms.org.br 
Tabela 2. Características microscópicas de isolados Curvularia spp. obtidos de lesões foliares de cultivares de milho em Gurupi-Tocantins.

\begin{tabular}{ccccccc}
\hline \multicolumn{7}{c}{ Características microscópicas } \\
(conídio)
\end{tabular}

*(Hilo - Presença ou ausência; Tamanho dos conídios - sendo c: comprimento e 1: Largura).

gênero Curvularia é relativamente fácil, no entanto, a identificação em nível de espécie pode ser complicada pelas descrições vagas e ausência de ilustrações em trabalhos mais antigos, inconstância de características morfológicas e microscópicas dos conídios.

Com relação à caracterização morfológica ao microscópio (Tabela 2), os conídios se mostraram semelhantes em todas as características analisadas. Contudo, a presença do hilo variou entre os isolados, assim como o número de septos, que variou entre dois e três; os conídios tinham o formato sempre curvado e o tamanho deles teve uma média de 22,36 x 11,62 $\mu \mathrm{m}$ (Figura 1). Estudos realizados com conídios de B. sorokiniana revelaram a existência de variações morfológicas no tamanho e na forma quando produzidos em diferentes substratos (Ellis, 1971; Sivanesan, 1987).
Estudos realizados por Ferreira (2010), empregando uma série de isolados de Curvularia, mostrou que algumas características do gênero, tais como conídio liso ou verrugoso; hilo (presente, ausente ou indistinto), 4 ou 5 células; conídio elipsoide ou cilíndrico; curvado ou não e formação de clamidósporos, sugeriram a existência de diferentes espécies, intergrupos e intragrupos. Dessa forma, Ellis (1971) descreveu a espécie Curvularia lunata com as seguintes características: conidióforos eretos com coloração marrom, podendo ser simples ou ramificados, em linha reta ou curva, apresentando conídios na parte apical e lateral do conidióforo, 3 a 4 células com duas células centrais, coloração marrom, curva maior nas penúltimas células, e hilo presente na maioria das vezes. 
Neste trabalho foi possível estabelecer uma relação entre as características morfológicas avaliadas com as descritas na literatura (Ellis, 1971). Contudo, segundo Sun et al. (2003), apenas a análise morfológica não fornece informações suficientes para identificação segura de espécies do gênero Curvularia, pois para uma identificação mais precisa é necessário proceder a análise baseada em dados moleculares.
Quanto à caracterização molecular, podemos observar na Figura 2 a eficiência do protocolo de extração de DNA para os isolados em estudo. O DNA total extraído foi utilizado como molde para a reação de PCR, utilizando-se primers específicos (gene $C \lg 2 p$ ) para Curvularia lunata (Hou et al., 2013). Todos os isolados apresentaram o mesmo padrão de amplificação, com o tamanho esperado ( $\cong 966 \mathrm{pb})$, caracterizando, assim, estes isolados como C. lunata (Figura 3).

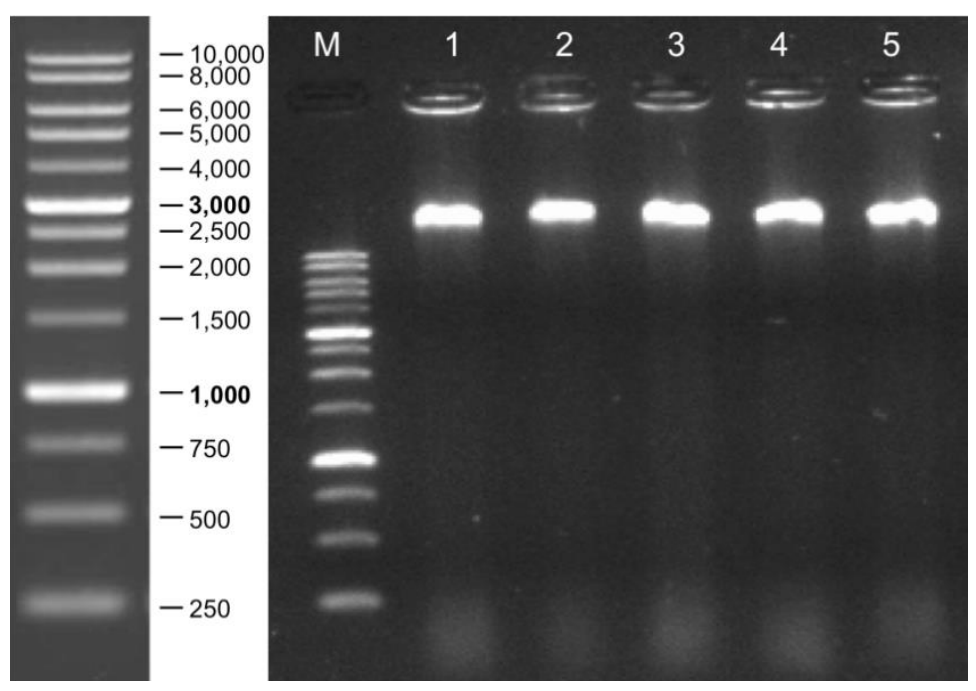

Figura 2. Eletroforese em gel de agarose do DNA total extraído dos isolados de milho. $\mathrm{M}=$ Marcador de peso molecular (Kasvi); 1: BRS 1040; 2: BM2202; 3: Traktor; 4: Attack e 5: Milho crioulo.

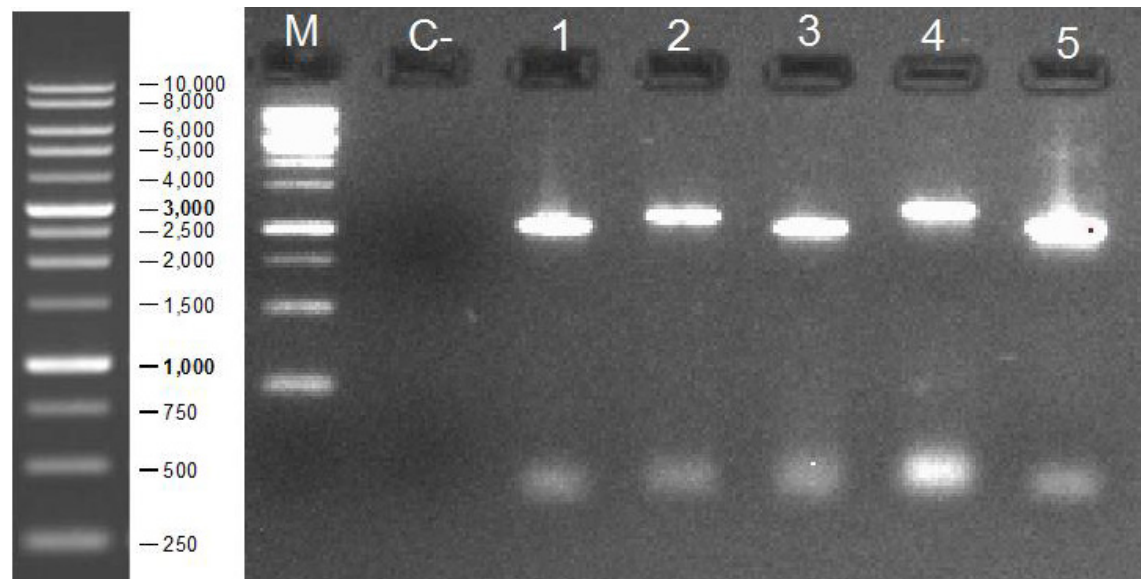

Figura 3. Eletroforese em gel de agarose dos produtos de amplificação com os primers específicos para $C$. lunata. M: Marcador de peso molecular de 1Kb (Kasvi); C-: controle negativo;1: BRS1040; 2: BM2202; 3 : Traktor; 4: Attack e 5: Milho crioulo. 
Técnicas moleculares, baseadas na análise do DNA, são frequentemente utilizadas como ferramenta auxiliar para caracterização morfológica de fungos fitopatogênicos (Brasileiro et al., 2004). A técnica de PCR para identificação em nível molecular de microrganismos tem sido extensivamente utilizada, pois se torna uma alternativa confiável e econômica.

A análise do padrão de restrição de produtos de amplificação do DNA da região ITS (Internal Transcribed Spacer) é outra técnica utilizada para a caracterização de fungos. A análise do perfil de restrição da região ITS tem sido amplamente utilizada em várias espécies de fungos patogênicos (Oliveira \& Costa 2002; Brasileiro et al., 2004; Chehri et al., 2011). Esta região separa os genes $18 \mathrm{~S}$ e $28 \mathrm{~S}$ do rDNA, e que pode ser amplificada com primers específicos ancorados nessas duas regiões, sendo altamente con- servada intraespecificamente, mas variável entre diferentes espécies, o que possibilita a distinção ao nível específico (Fungaro, 2000). A Figura 4 mostra o perfil de amplificação da região ITS dos isolados de Curvularia, mostrando um fragmento de aproximadamente $700 \mathrm{pb}$ e o controle positivo $\cong 600 \mathrm{pb}$. Esse resultado condiz com informações da literatura que mostram uma variação de tamanho de 400 a 900 pb para a região ITS em todas as espécies de fungos estudados (Brasileiro et al., 2004). A análise de restrição com a enzima HaeIII também produziu um padrão de banda igual para todos isolados (Figura 5).

De modo geral, as técnicas empregando informações contidas no DNA representam ferramentas complementares aos métodos de caracterização morfológica e bioquímica, minimizando assim possíveis erros na identificação. A análise de sequências de

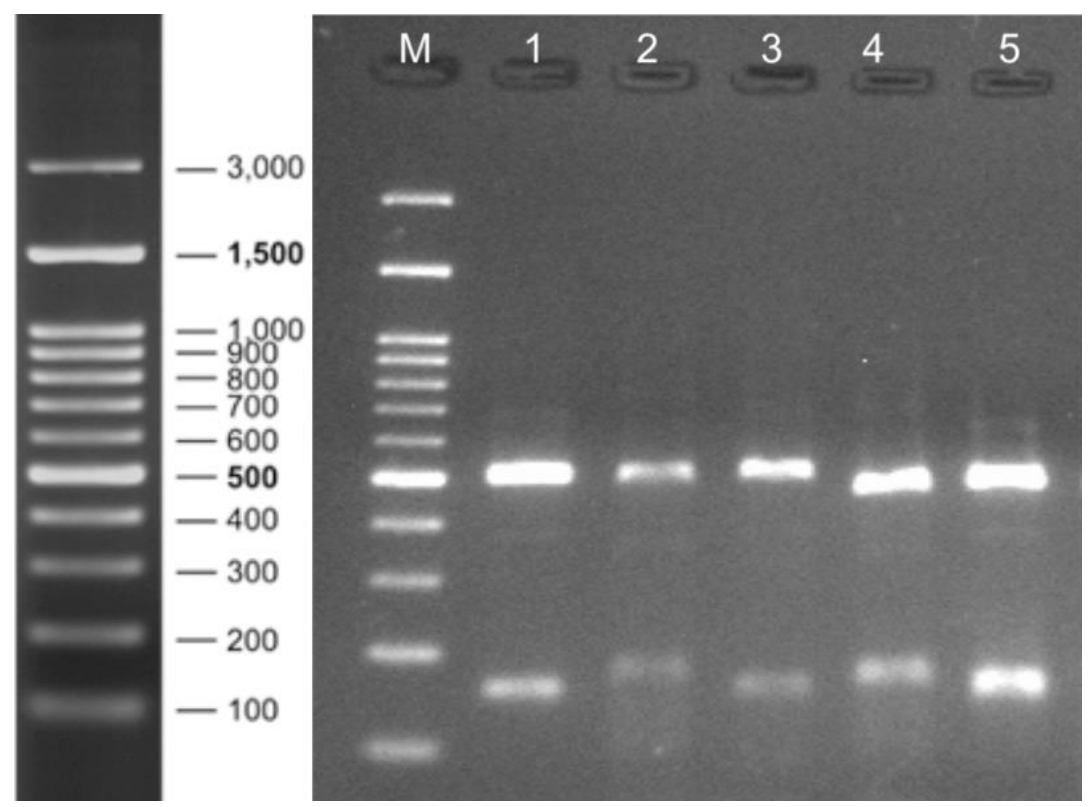

Figura 4. Eletroforese em gel de agarose dos produtos de amplificação com os primers ITS1 e ITS4. M: Marcador de peso molecular 1kb (Kasvi); C+: Fusarium verticilioides, C-: controle; 1: BRS 1040; 2 : BM2202; 3: Traktor; 4: Attack e 5: Milho crioulo. 


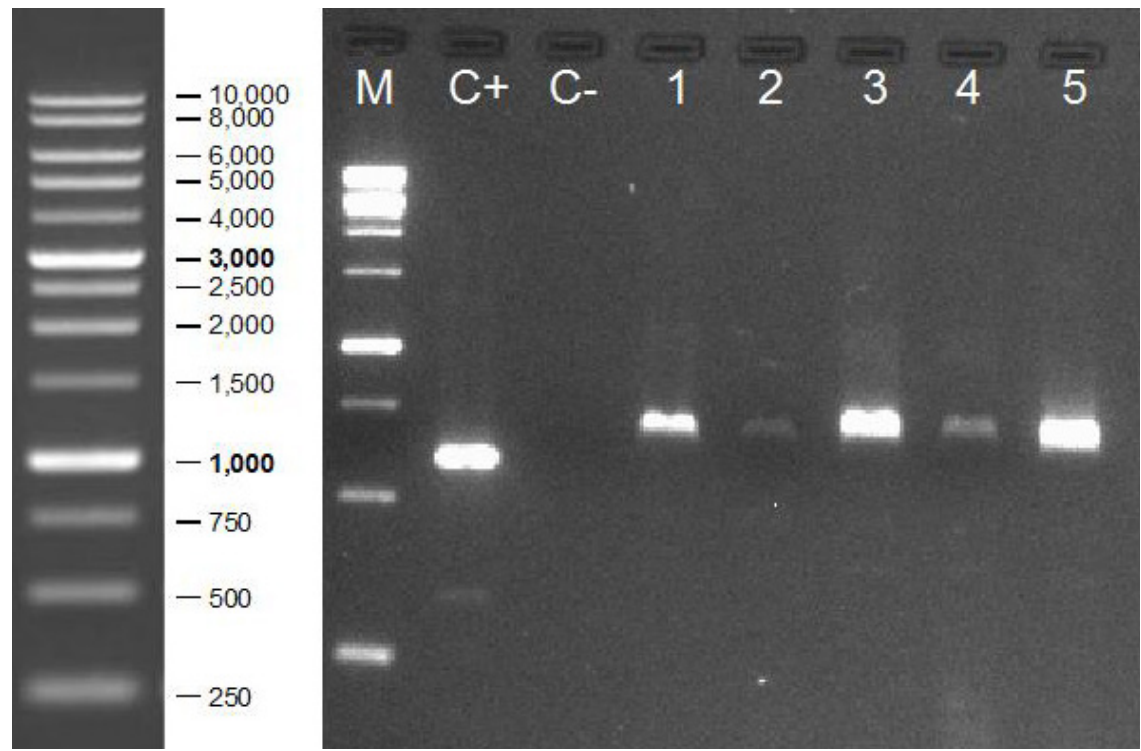

Figura 5. Perfil de restrição com a enzima HaeIII dos fragmentos amplificados da região ITS. M: Marcador de peso molecular de 100 pb (Kasvi); 1: BRS1040; 2: BM2202; 3: Traktor; 4: Attack e 5: Milho crioulo.

DNA, seja pelo padrão de restrição, seja pelo sequenciamento para determinar a sequência de nucleotídeos do fragmento amplificado por PCR, tem sido bastante empregada para a identificação de isolados e cepas ao nível de gêneros e espécies. O presente estudo relata pela primeira vez a ocorrência de Curvularia lunata, na região sul do Estado do Tocantins.

\section{Conclusões}

De acordo com as análises morfológicas de identificação macroscópica e microscópica do patógeno, foi possível estabelecer que os isolados estudados se agruparam em um único gênero.

Através da técnica de PCR empregando primers espécie-específicos para amplificação do gene $C \lg 2 p$ e da análise do padrão de restrição do fragmento de DNA da região ITS, foi possível identificar com precisão a patogenicidade dos isolados às plantas de milho, e determinar sua afiliação taxonômica à espécie Curvularia lunata.

\section{Referências}

AFFÉRRI, F. S.; CARVALHO, E. V. de; PELUZIO, J. M.; FRANCISCO, E. R.; NAZARENO, A. C.; FIDELIS, R. R. Adaptabilidade e estabilidade de genótipos de milho no Estado do Tocantins: safra 2003/2004. In: CONGRESSO NACIONAL DE MILHO E SORGO, 27.; SIMPÓSIO BRASILEIRO SOBRE A LAGARTADO-CARTUCHO, SPODOPTERA FRUGIPERDA, 3.; WORKSHOP SOBRE MANEJO E ETIOLOGIA DA MANCHA BRANCA DO MILHO, 2008, Londrina. Agroenergia, produção de alimentos e mudanças climáticas: desafios para milho e sorgo: trabalhos e palestras. [Londrina]: IAPAR; [Sete Lagoas]: Embrapa Milho e Sorgo, 2008. 6 p.

BRASILEIRO, B. T. R. V.; COIMBRA, M. R. M.; MORAIS, M. A.; OLIVEIRA, N. T. Genetic variability within Fusarium solani specie as reveled by PCR- 
fingerprint based on PCR markers. Brazilian Journal of Microbiology, São Paulo, v. 35, n. 3, p. 205-210, 2004.

DOI: $10.1590 / \mathrm{S} 1517-83822004000200006$.

CASA, R. T.; REIS, E. M.; ZAMBOLIM, L. Doenças do milho causadas por fungos do gênero Stenocarpella. Fitopatologia Brasileira, Brasília, DF, v. 31, n. 5, p. 427 439, 2006.

DOI: $10.1590 / \mathrm{S} 0100-41582006000500001$.

CHEHRI, K.; SALLEH, T.; YLI-MATTILA, K. R. N.; REDDY, S.; ABBASI, S. Molecular characterization of pathogenic Fusarium species in cucurbit plants from Kermanshah province, Iran. Saudi Journal of Biological Sciences, v. 18, n. 4, p. 341-351, 2011.

DOI: $10.1016 /$ j.sjbs.2011.01.007.

CRUZ, J. C. (Ed.). Cultivo do milho. 6. ed. Sete Lagoas: Embrapa Milho e Sorgo, 2010. (Embrapa Milho e Sorgo. Sistema de produção, 1).

CRUZ, J. C.; VERSIANI, R. P.; FERREIRA, M. T. R. (Ed.). Cultivo do milho. 7. ed. Sete Lagoas: Embrapa Milho e Sorgo, 2011. (Embrapa Milho e Sorgo. Sistema de produção, 1).

DUARTE, J. de O.; GARCIA, J. C.; MIRANDA, R. A. de. Economia da produção. In: CRUZ, J. C. (Ed.). Cultivo do milho. 8. ed. Sete Lagoas: Embrapa Milho e Sorgo, 2012. (Embrapa Milho e Sorgo. Sistema de produção, 1).

ELDER, J. F. JR.; TURNER, B. J. Concerted evolution of repetitive DNA sequences in eukaryotes. The Quarterly Review of Biology, New York, v. 70, n. 3, p. 297-320, 1995.

ELLIS, M. B. Dematiaceous Hyphomycetes. Surrey: CAB, $1971.608 \mathrm{p}$.

FERREIRA, L. S. Caracterização de isolados de Curvularia ssp. Endofíticos de milho (Zea Mays L.) por parâmentros morfológicos e moleculares. 2010. Dissertação (Mestrado) - Universidade Federal do Paraná, Curitiba, 2010.
FUNGARO, M. H. P. PCR na micologia. Biotecnologia Ciência e Desenvolvimento, Uberlândia, v. 3, n. 14, p. 12$16,2000$.

GALVÃO, J. C. C.; MIRANDA, G. V.; TROGELLO, E.; FRITSCHE NETO, R. Sete décadas de evolução do sistema produtivo da cultura do milho. Revista Ceres, Viçosa, MG, v. 61, p. 819-828, 2014.

DOI: $10.1590 / 0034-737 \times 201461000007$.

HOU, J. M.; MA, B. C.; ZUO, Y. H.; GUO, L. L.; GAO, S. G.; WANG, Y. Y.; LIU, T. Rapid and sensitive detection of Curvularia lunata associated with maize leaf spot based on its Clg2p gene using semi-nested PCR. Letters in Applied Microbiology, Oxford, v. 56, n. 4, p. 245-250, 2013. DOI: 10.1111/lam.12040.

PIMENTEL, I. C.; GLIENKE-BLANCO, C.; GABARDO, J.; STUART, R. M.; AZEVEDO, J. L.; Identification and colonization of endophytic fungi from soybean (Glycine $\max (\mathrm{L})$ Merril) under different environmental conditions. Brazilian Archives of Biology and Technology, Curitiba, v. 49, n. 5, p. 705-711, 2006.

DOI: $10.1590 / \mathrm{S} 1516-89132006000600003$.

KERN, M. E.; BLEVINS, K. S. Micologia médica: texto $\&$ atlas. 2. ed. São Paulo: Premier, 1999.

LIMA, A.; FURTADO, M. Curvularia species (anamorphic fungi: Hyphomycetes) from Santiago island, Cape Vert. Portugaliae Acta Biologica, Lisboa, v. 22, n. 1/4, p. 145156, 2007.

LONG, E. O.; DAWID, I. B. Repeated Genes in Eukaryotes. Annual Review of Biochemistry, Palo Alto, v. 49, p. 727 764. 1980.

DOI: 10.1146/annurev.bi.49.070180.003455.

MAGALHÃES, P. C.; DURAES, F. O. M. Ecofisiologia. In: CRUZ, J. C.; VERSIANI, R. P.; FERREIRA, M. T. R. (Ed.). Cultivodomilho.8.ed.SeteLagoas:EmbrapaMilhoeSorgo, 2011. (Embrapa Milho e Sorgo. Sistema de produção, 1).

OLIVEIRA, V. C.; COSTA, J. L. S. Análise de restrição de DNA ribossomal amplificado (ARDRA) pode diferenciar 
Fusarium solani f. sp. phaseoli de F. solani f. sp. glycines. Fitopatologia Brasileira, Brasília, DF, v. 27, n. 6, p. 631634, 2002.

DOI: $10.1590 / \mathrm{S} 0100-41582002000600013$.

REIS, E. M.; CASA, R. T.; BRESOLIN, A. C. R. Manual de diagnose e controle de doenças do milho. 2. ed. Lages: Graphel, 2004.

SIVANESAN, A. Graminicolous species of Bipolaris, Curvularia, Drechslera, Exserohilum and their teleomorphs. Wallingford: $\mathrm{CAB}$ International Mycological Institute, 1987.

SUN, G.; OIDE, S.; TANAKA, E.; SHIMIZU, K.; TANAKA, C.; TSUDA, M. Species separation in Curvularia "geniculata" group inferred from $\mathrm{Brnl}$ gene sequences. Mycoscience, Tokyo, v. 44, p. 239-244, 2003.
VAZ-DE-MELO, A.; AFFÉRRI, F. S.; DOTTO, M. A.; PELUZIO, J. M.; SANTOS, G. R.; CARVALHO, E. V. Reação de híbridos de milho à Curvularia ssp, sob dois níveis de adubação com nitrogênio, no sul do Tocantins. Scientia Agraria, Curitiba, v. 11, n. 2, p. 149-154, 2010.

WHITE, T. J.; BRUNS, T.; LEE, J.; TAYLOR, J. W. Amplification and direct sequencing of fungal ribosomal RNA genes for phylogenetics. In: INNIS, M. A.; GELFAND, D. H.; SNINSKY, J. J.; WHITE, T. J. (Ed.). PCR Protocols: a guide to methods and applications. New York: Academic Press, 1990. p. 315-322.

WHITE, D. G. Compendium of corn diseases. 3. ed. Saint Paul: The American Phytopathological Society, 1999. 78 p.

ZOLAN, M. E.; PUKILLA, P. J. Inheritance of DNA methylation in Coprinus cinerus. Molecular and Cellular Biology, v. 6, n. 1, p. 195-200, 1986. 